
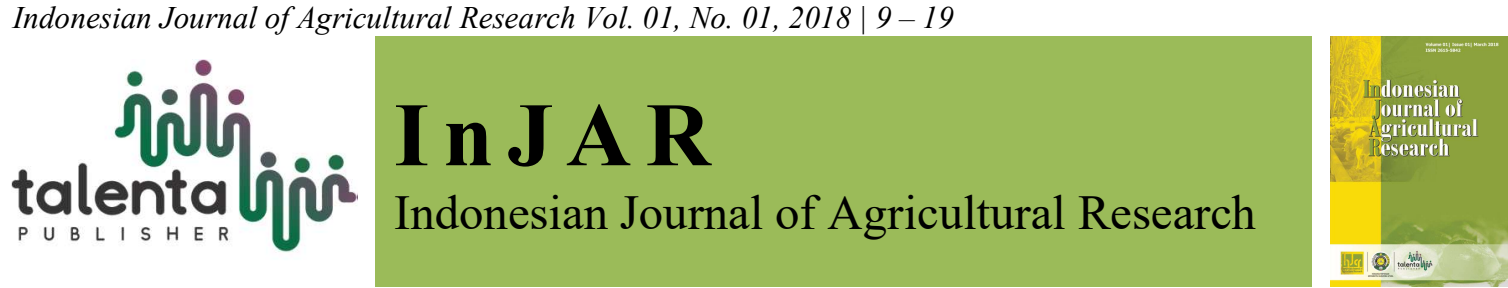

\title{
Legume Plant Growth at Various Levels of Drought Stress Treatment
}

\author{
Veronica Sinamo, Nevy Diana Hanafi, and Tri Hesty Wahyuni \\ Animal Husbandry Study Program, Faculty of Agriculture, Universitas Sumatera Utara, Indonesia
}

\begin{abstract}
A strategic alternative step for the development of cultivation of feed crops is to optimize the use of dry land that has the potential for agricultural and livestock business. One of the forage plants that has good adaptation to less good soil condition and is a pioneer plant, Pueraria javanica legume, so it can be considered as a potential alternative forage as animal feed. The research aims at determining the effect of various levels of drought stress treatment on the plant hight, fresh matter production, dry matter production and root biomass of Pueraria javanica legume. The experiment was conducted in the Greenhouse of the Agriculture Faculty of Universitas Sumatera Utara. The experiment was carried out using a completely randomized design (CRD) with 3 treatments and 4 replications. The treatments were A1 (25\% field capacity (FC)=144 ml/polybag, A2 (50\% $\mathrm{FC})=288 \mathrm{ml} /$ polybag and A3 $(100 \% \mathrm{FC})=576 \mathrm{ml} /$ polybag. The results show that Pueraria javanica legume can survive and grow up to severe drought stress $(25 \% \mathrm{FC})$ but the crop production does not increase when compared to the field capacity condition; besides, the legume cannot survive longer in drought condition. The volume of water supplied corresponding to the field capacity makes the plant growth better.
\end{abstract}

Keywords: drought stress, growth, latosol soil, Pueraria javanica

Received 01 March 2018 | Revised 29 March 2018 | Accepted 30 March 2018

\section{Introduction}

North Sumatra has a very large potential of forage that can be used as a good source for livestock feed. However, such source of feed is seasonal and needs forage planting to maintain the continuity of forage availability which becomes one of the important factors in the livestock business, so it needs to be addressed with various optimal innovations.

The most strategic alternative step of developing the cultivation of feed plants is through the optimization of dry land use which is one of the agro-ecosystems that has great potential for agriculture, such as food crops, horticulture (vegetables and fruits), annual crops and livestock. The potential of dry land in Indonesia is very large (about 148 million ha), and only about 76.22 million ha of which can be utilized as productive dry land. Particularly in North Sumatra, only 3.12 million ha of dry land is still in use. Based on the data from the Center for Soil and

\footnotetext{
*Corresponding author at: Animal Husbandry Study Program, Faculty of Agriculture, Universitas Sumatera Utara, Jl. Prof. Sofyan No. 3, Medan 20155, Indonesia

E-mail address: njuahnjuah30@yahoo.com
} 
Agroclimate Research and Development in 2001, the area of dry land in Sumatra suitable for agriculture on the lowland is 4,899.476 ha for seasonal crops and 15,848,203 ha for annual crops, while the area on the highland is $1,103.18$ ha for seasonal crops and 992.05 ha for annual crops by BPS [1].

According to Purwaningsih [2], the largest type of soil in the area of Bukit Barisan (Sumatra) is latosol land whose soil $\mathrm{pH}$ is 4.3. The soil acidity determines the level of mineral fixation in the soil. In the too acidic soil $(\mathrm{pH}<6.0)$, the availability of $\mathrm{P}$ decreases due to the presence of $\mathrm{Fe}$ and $\mathrm{Al}$, deep solum, clay texture, easy water absorption, medium organic matter and brown, red and yellow colors [3].

The water content on dry soil is necessary to know in order to determine the amount of water needs to be given to the land by considering the field capacity. According to Kurnia et al. [3], the field capacity is very important because it can show the maximum soil content and can determine the amount of irrigation water required to wet the soil and its underlying layer. According to Thorne [4], water in the soil is one of the important factors in crop production. Water should be available in the soil to replace lost water due to evaporation of the soil and transpiration of the plant. Water in the soil always carries nutrients in its solution for plant growth.

Plants suffering from a long-term drought will experience morphological, anatomical, physiological and biochemical changes that cannot be recovered and that can cause death. One of legume plants that is tolerant to drought stress, even in the long-term drought, and that can adapt to the acidic land conditions is Pueraria javanica.

According to Reksohadiprodjo [5], Pueraria javanica is resistant to acid soils and soils lacking lime and phosphorus, can live in clay and sandy land and is tolerant against short-term drought stress. In addition, Maulidesta [6] states that Pueraria javanica legume belongs to a pioneer plant, a good quality livestock feed with high ability to suppress weed growth. Therefore, its existence can be considered as a potential forage alternative of animal feed. This study aims at determining the growth and productivity (plant height, fresh production, dry production, and root biomass) of Pueraria javanica legume at various levels of drought stress.

\section{Materials and Method}

\subsection{Research Setting}

This research was conducted in the experimental field of the Faculty of Agriculture, Universitas Sumatera Utara. This research had been conducted for approximately 5 months from September 2016 to January 2017. 


\subsection{Research Materials and Tools}

The materials used were one month old of Pueraria javanica legume as the observation object, water as the research treatment material, brown latosol soil and compost as the planting medium. The tools used were small and large polybags for planting crops, rolling tape measure for measuring the plant height, paper bags as the sampling plant container in the oven, digital scale of $3000 \mathrm{~g}$ capacity to weigh the production of fresh materials, electric scale to weigh the production of dry materials, an oven to dry the sample in calculating the dry material production, aluminum plate as the container of material to be put into the oven $\left(105^{\circ}\right)$, desiccator to cool the sample and stationery.

\subsection{Research Method}

This research used a complete randomized design method replicated 4 times and observed on one legume type. Thus, the total number of experiments was 12 units. The treatments conducted in this research were: $\mathrm{A} 1=$ severe drought stress $(25 \% \mathrm{FC})$ of $144 \mathrm{ml} /$ polybag; $\mathrm{A} 2$ = medium drought stress $(50 \% \mathrm{FC})$ of $288 \mathrm{ml} /$ polybag; A3 = non-drought stress $(100 \% \mathrm{FC})$ of 576 $\mathrm{ml} /$ polybag. The type of legume serving as the object of this research was: Pueraria javanica. Using the experiment model:

$$
\text { Yij }=\mu+\mathrm{Ti}+\varepsilon i j ; \quad(i=1,2,3, \ldots \ldots \ldots . . ; j=1,2,3, \ldots \ldots \ldots . .)
$$

Note: $\mathrm{Yij}=$ observation value at the $\mathrm{i}$ treatment, the $\mathrm{j}$ replication; $\mu=$ the common middle value; $\mathrm{Ti}=$ the effect of the $\mathrm{i}$ treatment; $\varepsilon \mathrm{ij}=$ the random effect of the $\mathrm{i}$ treatment and the $\mathrm{j}$ replication.

\subsection{Observed Variables}

The variables observed in this research were:

a. Plant height

Plant height measurements were carried out to determine the plant growth rates. The plant height measurements were conducted once a week using a 4-meter-rolling tape measure, from the base of the plant above the soil to the tip of the canopy. The total height measurement of the plant was done by erecting the leaf of the plant and then measuring from the tip of the root to the tip of the leaf by Ibrahim [7].

\section{b. Fresh production}

The fresh production of Pueraria javanica legume was obtained from the harvest which was weighed after each of the first cuts and the second cuts without administering such treatment as drying. The weighing of fresh production of Pueraria javanica legume was done every harvest, the $1^{\text {st }}$ harvest and the $2^{\text {nd }}$ harvest. At the $1^{\text {st }}$ harvest, the plant was 3 month old, and the interval between the $1^{\text {st }}$ harvest and the $2^{\text {nd }}$ harvest was 32 days. 


\section{c. Dry matter production}

The production of dry matter was obtained from the fresh matter production of Pueraria javanica legume after weighing. The legume was then put into the oven at $60{ }^{\circ} \mathrm{C}$ for 24 hours and then weighed. Then, $2 \mathrm{~g}$ of the dried legume was taken as the sample and was put into the oven at $105^{\circ} \mathrm{C}$ for 8 hours and then weighed. The fresh weight production was converted into the dry weight to determine of dry weight. To calculate the production of dry weight of the plants, the following formula was applied:

$$
\text { Production of dry matter weight }=\mathrm{DM} \text { content }(\%) \mathrm{x} \text { fresh production }
$$

\section{d. Root biomass}

Root biomass can be calculated at the final harvest because the root growth in the early, middle and final growth is not the same in terms of root length and weight. The calculation of root biomass was done by cutting the root border, cleaning the root from the sticking soil and weighing the cleaned roots. Root biomass was calculated at the time of the final harvest.

\subsection{Research Implementation}

a. Materials and tools preparation

The materials and tools were the first matters that should be prepared. The Pueraria javanica legume to be planted was young plant (1 month old) experiencing a perfect growth including its roots, stems and leaves. The soil to be used as the planting media is brown latosol soil free from weeds and ready-made compost.

\section{b. Field Capacity (FC) Determination}

Field capacity is the ability of soil particles to hold as much water as possible against gravity. The field capacity (FC) determination was conducted to determine the watering volume. 7 pieces of 1-kilogram-pot were filled with $500 \mathrm{~g}$ of planting media each. All the pots were watered until they got saturated then was left for $3 \times 24$ hours until the water stopped dripping. The result was then weighed as the wet weight (WW). The planting media were put into the oven at $100^{\circ} \mathrm{C}$. After 24 hours, the planting media were taken out from the oven to be cooled in a desiccator, and then were weighed as the dry weight (DW). To get the average result, the experiment was replicated 5 times. After that, the field capacity (FC) of the land was calculated using the following formula:

$$
\mathrm{FC}=(\mathrm{WW}-\mathrm{DW}) \times 100 \% \mathrm{DW}[8]
$$

The result of the calculation from the observation of field capacity determination was as follows:

$$
\mathrm{FC}=\frac{730.57-538.57}{538.57} \times 100 \%
$$


$\mathrm{FC}=0.357 ; \mathrm{FC}=35.7 \%=36 \mathrm{ml}$

$\mathrm{FC}=36 \mathrm{ml}$ in $500 \mathrm{~g}$ of planting media of brown latosol + compost, so $8 \mathrm{~kg}$ of planting media required water volume of $576 \mathrm{ml}$ ( 0.5 liters).

So: Severe drought stress $(25 \% \mathrm{FC})$ required a watering volume of $144 \mathrm{ml}$, Medium drought stress (50\% FC) required a watering volume of $288 \mathrm{ml}$, Non-drought stress (100\% FC) required a watering volume of $576 \mathrm{ml}$.

c. Soil water content determination

The soil sample was collected as much as $5 \mathrm{~g}$ in each potted plant then was put into the oven at $105{ }^{\circ} \mathrm{C}$. After 24 hours, the sample was weighed. The water content was obtained from the sample weight before oven drying subtracted by the sample weight after oven drying divided by the sample weight after oven drying multiplied by $100 \%$.

$$
\text { Soil water content }=\frac{\text { wo-wt }}{\text { wo }} \times 100 \%
$$

Notes:

$\mathrm{W} 0=$ weight of the soil sample before oven drying

$\mathrm{Wt}=$ weight of the soil sample after oven drying

Based on the observation results, the soil water content in the control treatment $(100 \% \mathrm{FC})$ was $85.32 \%$, the soil water content in the medium drought stress ( $50 \%$ FC) was $43.56 \%$, and the soil water content in the severe drought stress was $24.42 \%$.

\section{d. Planting}

Planting Pueraria javanica legume was done by planting the perfectly grown 1 month old plant nurtured in small polybags each of which was filled by one Pueraria javanica legume plant, and the watering was done regularly, i.e. twice a day until the plants got 2 months old.Then, the plant was moved into a large polybag ( $10 \mathrm{~kg}$ polybag) which had been filled with $8 \mathrm{~kg}$ of the planting media, 2/3 of which was filled with latosol soil and the other $1 / 3$ of which was filled with compost. After that, the plants came into adaptation period for one month.

e. Plant nurturing and treatment implementation

The plant nurturing steps were: 1) Watering the plants. The plants were watered regularly twice a day (i.e. every morning and evening) until the plants reached one month old. During the adaptation period when the plants were already one month to two months old, watering was done once a day in the morning. The treatment of drought stress was given after the plants had been 60 days after planting. The amount of water was adjusted to the field capacity. The plants under treatment consisted of 3 levels of drought stress: 100\% drought stress level (water volume $576 \mathrm{ml}$ ), drought stress level 50\% (water volume $288 \mathrm{ml}$ ) and drought stress $25 \%$ (water volume 
$144 \mathrm{ml})$. Watering was done once a day, and all polybags were put in a place free from rain water; 2) Weeding. It was done manually with the aim of cleaning the weeds around the plants.

f. Data collection and harvesting

The data collected consisted of fresh production, i.e. the weight of the plants which was weighed after cutting.

1. The production of dry materials, i.e. the weight of the plants which was weighed after the plants had been dried and put in the oven for 24 hours at a temperature of $60{ }^{\circ} \mathrm{C}$ and for 8 hours at $105{ }^{\circ} \mathrm{C}$ and was then converted.

2. The plant height obtained from weekly plant measurements after the plants had been treated.

3. Root biomass calculated by cutting the root limit, cleaning the root from the soil attached, weighing and observing the root's weight and length.

The data collection began once the treatment to the plants started until the final harvest. The plants were harvested twice with harvesting interval of 32 days.

\section{g. Data Analysis}

The data obtained were analyzed by using variance (Anova) test. If a significant difference were found, the analysis would proceed to Duncan test.

\section{Results and Discussion}

\subsection{Height of Pueraria javanica Legume Plant}

The plant height was one of the components of plant growth or an indicator often observed in the plant growth or a parameter used to measure the plant growth. The height growth of the legume was strongly influenced by the available water content inside the soil. The height of Pueraria javanica legume at the first and second cuts (32 day intervals) can be seen in Table 1.

Table 1. Average Height (cm/week) of Pueraria javanica Legume

\begin{tabular}{|c|c|c|c|c|c|c|}
\hline \multirow{2}{*}{ Treatments } & \multicolumn{4}{|c|}{ Replication } & \multirow{2}{*}{ Total } & \multirow{2}{*}{ Average $^{\mathrm{n}}$} \\
\hline & 1 & 2 & 3 & 4 & & \\
\hline A1 & 91.83 & 96.83 & 103.33 & 78.00 & 370.00 & 92.50 \\
\hline A2 & 102.67 & 248.17 & 129.00 & 87.67 & 567.50 & 141.88 \\
\hline A3 & 133.83 & 218.33 & 127.00 & 203.67 & 682.83 & 170.71 \\
\hline
\end{tabular}

Notes: ns: not significantly difference $(\mathrm{P}>0,05)$

The average height of the plants in Table 1 shows that the drought stress level gives insignificant effect to the height growth of Pueraria javanica legume. The highest average height of the plants that was found in A3 treatment (no drought stress: $100 \%$ field capacity (FC)) was $170.71 \mathrm{~cm}$ which was not significantly different from the average height of A1 
treatment (drought stress of $25 \% \mathrm{FC}$ ) and of A2 treatment (drought stress of $50 \% \mathrm{FC}$ ) which was $141.88 \mathrm{~cm}$ and $92.50 \mathrm{~cm}$, respectively.

This might occur because the soil water under A treatment (drought stress level) had a volume that did not vary very much among the three treatments (A1, A2 and A3) so that the plant height growth was also not too much different at the drought stress levels, i.e. drought stress of $50 \%$ FC, drought stress of $25 \% \mathrm{FC}$ and non-drought stress of $100 \% \mathrm{FC}$, whereas the amount of water availability in the soil was very influential on the plant growth. This is in line with the statement of Wayah et al. [9] that if the water requirement is not fulfilled, then the plant growth will be disturbed because the water serves to dissolve the nutrients and helps the metabolism process in the plant.

Pueraria javanica is a legume that is less tolerant to long-term drought. Based on the results of this research, the Pueraria javanica legume could survive up to the level of severe drought stress but there was a decreased growth in their height. This is the response of the plants to drought stress in order to survive; as Li et al. [10] state that plant response in dealing with drought stress with avoidance mechanisms includes reducing the leaf growth, decreasing the relative water content and reducing the number of branches. In addition, Cook et al.[11] argue that this legume is less resistant to drought, despite being survive within 4-5 months, it will suffer considerable leaf loss. Furthermore, Li et al. [10] add that drought stress decreases the relative rate of leaf expansion, leaf number, plant height, and canopy ratio; the roots depend on the stage of growth of the plant itself in the event of drought stress.

\subsection{Fresh Production of Pueraria javanica Legume}

The fresh production of forage served as the benchmark of plant growth quality on the response of plants to various environmental conditions. The fresh production was obtained from the total forage products while harvesting. The average fresh production of Pueraria javanica legume at the $1^{\text {st }}$ and $2^{\text {nd }}$ cuts ( 32 day intervals) can be seen in Table 2 .

Table 2. Average Fresh Production (g/pot) of Pueraria javanica Legume

\begin{tabular}{|c|c|c|c|c|c|c|}
\hline \multirow{2}{*}{ Treatments } & \multicolumn{4}{|c|}{ Replication } & \multirow{2}{*}{ Total } & \multirow{2}{*}{ Average } \\
\hline & 1 & 2 & 3 & 4 & & \\
\hline A1 & 36.90 & 30.75 & 36.75 & 53.40 & 157.80 & $39.45^{b}$ \\
\hline $\mathrm{A} 2$ & 38.60 & 37.15 & 41.60 & 44.35 & 161.70 & $40.43^{b}$ \\
\hline A3 & 65.50 & 62.35 & 97.15 & 83.55 & 308.55 & $77.14^{\mathrm{a}}$ \\
\hline
\end{tabular}

Notes: Superscripts with different letters show a significantly difference $(\mathrm{P}<0.05)$.

The results of the research presented in Table 2 show that the drought stress level has a significant effect on fresh production. The highest average of fresh production is found in the A3 treatment (non-drought stress of $100 \%$ FC), i.e. $77.14 \mathrm{~g}$, which is significantly different from the A1 treatment (drought stress of $25 \%$ FC), i.e. $39.45 \mathrm{~g}$. The result in the A1 treatment is 
not also significantly different from the average result in the A2 treatment (drought stress of $50 \% \mathrm{FC})$, i.e. $40.43 \mathrm{~g}$.

The results of the research showed that the production of fresh Pueraria javanica legume was different on every level of drought stress. The less water content was supplied to the legumes the more the production of fresh legumes decreased. Therefore, if the plant environment lacked of water, the plant stomata would narrow down and this disrupted the process of photosynthesis causing plants lack of nutrients for growth leading to decreased production of the plants.

This was the legumes response to drought to survive under water shortages. According to Nilsen and Orcutt [12], the first response of plants to severe water shortage conditions is by closing their stomata. Closing and/or narrowing the stomata inhibit the process of photosynthesis which involves the transport of water in the body of plants and the decrease in the flow of carbon dioxide in their leaves. In relation to the decreased concentration of carbon dioxide in leaves, $\mathrm{Li}$ et al. [10] argue that the response of plants in facing the drought stress is through avoidance mechanisms, such as reducing the leaf growth, decreasing the relative water content and reducing the number of branches. Drought stress decreases the relative rate of leaf expansion, leaf number, plant height, and canopy ratio: the roots depend on the stage of growth of the plant itself in the event of drought stress.

\subsection{Dry Matter Production of Pueraria javanica Legume}

According to Kartadisastra [13], dry matter is a non-aqueous feed material, and according to Immawatitari [14], dry material is one of the results of the fractional division derived from feed ingredient after its water content is reduced. The average dry material of the Pueraria javanica legumes with the severe drought stress ( $25 \%$ FC) was $144 \mathrm{ml}$, with the medium drought stress $(50 \% \mathrm{FC})$ was $288 \mathrm{ml}$ and with the non-drought stress $(100 \% \mathrm{FC})$ was $576 \mathrm{ml}$. The different results for each of the treatments can be seen in Table 3 .

Table 3 shows that the highest average of dry production in the Pueraria javanica legume is in the A3 treatment (non-drought stress of $100 \% \mathrm{TC}$ ), $20.88 \mathrm{~g}$, which is significantly different from the A1 treatment (drought stress of $25 \% \mathrm{FC}$ ), i.e. $10.16 \mathrm{~g}$, and the A2 treatment (drought stress of $50 \%$ FC), i.e. $14.40 \mathrm{~g}$.

Table 3. Average Dry Matter Production of The Pueraria javanica Legume (g/polybag)

\begin{tabular}{|c|c|c|c|c|c|c|}
\hline \multirow{2}{*}{ Treatments } & \multicolumn{4}{|c|}{ Replication } & \multirow{2}{*}{ Total } & \multirow{2}{*}{ Average } \\
\hline & 1 & 2 & 3 & 4 & & \\
\hline $\mathrm{A} 1$ & 10.145 & 10.15 & 10.15 & 10.2 & 157.80 & $10.16^{\mathrm{C}}$ \\
\hline $\mathrm{A} 2$ & 14.65 & 14.30 & 14.30 & 14.35 & 161.70 & $14.40^{\mathrm{B}}$ \\
\hline $\mathrm{A} 3$ & 21.06 & 20.75 & 20.85 & 20.85 & 308.55 & $20.88^{\mathrm{A}}$ \\
\hline
\end{tabular}

Notes: Superscripts with different letters show a highly significant difference $(\mathrm{P}<0.01)$ 
The result of variance analysis showed that the drought stress level had a high significantly different $(\mathrm{P}<0.01)$ on dry matter production. This was supported by average of dry matter production of Pueraria javanica legume. The results of the analysis presented in Table 3 show that the higher the drought stress level is, the higher the production of dry plant material will be. At the A1 treatment (drought stress of $25 \% \mathrm{FC}$ ), the dry production is also lower than other treatments.

The result of dry matter production is in line with fresh production, and the different result is only due to the amount of water supplied varies in each treatment. The small amount of water at $25 \% \mathrm{FC}$ of drought stress is not sufficient for legumes so that the growth of legumes in the A1 treatment is different from the A2 treatment and A3 treatment. This is in line with the statement of Wayah et al. [9] that if the water requirement is not fulfilled, then the plant growth will be disturbed because the water serves to dissolve the nutrients and helps the metabolism process in the plant. Another similar statement is also mentioned by Sitompul and Guritno ([15] who state that the measurement of the growth process can be measured through the increase of the plant height, the number of leaves, the fresh production, the dry production and the diameter of the plant. The parameters of wet weight or fresh weight cannot completely be used as a measure of plant growth, this is due to the frequent heavy fluctuations that depend on the moisture of the plant.

\subsection{Biomass Roots of Pueraria javanica Legume}

Root biomass was one of the parameters in measuring the growth rate of plants living in various environmental conditions either beneficial or detrimental to the plants themselves. The average root biomass of the legume plants in the severe drought stress $(25 \% \mathrm{FC})$, medium drought stress ( $50 \%$ TOS) and non-drought stress (100\% FC) for each treatment can be seen in Table 4.

Table 4 shows that the highest average of root biomass on Pueraria javanica legume was in the A3 treatment (no drought stress $100 \% \mathrm{FC}$ ), i.e. $3.5500 \mathrm{~g}$, which was significantly different from the A1 treatment (drought stress 25\% FC) and the A2 treatment (drought stress 50\% FC). The root biomass in the $\mathrm{A} 2$ treatment was significantly different from the A1 treatment but was not significantly different from the A3 treatment.

This happened because the polybags used as the planting media in this research inhibited the growth and development of legume roots resulting in the round-shaped roots of Pueraria javanica legumes following the polybag's basic circular shape; therefore, the roots could not develop normally. This is in line with the statement of Susetyo et al. [16] that circular roots can inhibit plant growth especially at root length. In addition, the plants are also easily uprooted and susceptible to dry climatic conditions because of their relatively shallow roots. 
Table 4. Average of Root Biomass (g/pot) of Pueraria javanica Legumes

\begin{tabular}{|c|c|c|c|c|c|c|}
\hline \multirow{2}{*}{ Treatments } & \multicolumn{4}{|c|}{ Replication } & \multirow{2}{*}{ Total } & \multirow{2}{*}{ Average } \\
\hline & 1 & 2 & 3 & 4 & & \\
\hline A1 & 3.40 & 3.50 & 3.60 & 3.70 & 14.20 & $5.45^{\mathrm{a}}$ \\
\hline $\mathrm{A} 2$ & 3.70 & 3.80 & 3.77 & 3.75 & 15.02 & $3.76^{\mathrm{b}}$ \\
\hline $\mathrm{A} 3$ & 5.50 & 5.10 & 5.40 & 5.70 & 21.70 & $3.55^{\mathrm{b}}$ \\
\hline
\end{tabular}

Notes: Superscripts with different letters show a significantly difference $(\mathrm{P}<0.05)$.

\section{Conclusions and Recommendations}

Pueraria javanica legume can survive and grow up to severe drought stress (25\% FC) but the crop production does not increase when compared to the field capacity conditions; besides, the legume cannot survive longer in drought condition. The volume of water supplied corresponding to the field capacity makes the plant growth better. For the cultivation of Pueraria javanica legume on dry land of latosol, it is advisable to do composting or fertilizing in order to increase the plant growth.

\section{REFERENCES}

[1] Badan Pusat Statistik Sumatera Utara, Statistik data lahan pertanian 2010-2014. Sumatera Utara, Publikasi Indikator Pertanian, 2010.

[2] Purwaningsih, "Jenis tanah dan suhu," $2003 . \quad$ [Online]. Available: http://ningpurwaningsih.wordpress.com/2013/06/01/jenis-tanah-suhu-danciri.html.

[3] U. Kurnia, et al., "Penetapan retensi air tanah di lapangan," 2014. [Online]. Available: http:/balittNh.litbang.pertanian.go.id/ind/dokumentasi/buku/buku/sifat/tanah/retensi_air.pdf

[4] D. W. Thorne and M. D. Thorne, Soil, Water and Crop Production. USA: AVI Publishing Company, 2009.

[5] S. Reksohadiprodjo, Produksi Tanaman Hijauan Makanan Ternak Tropik. Yogyakarta: BPFE, 2005.

[6] N. Maulidesta, "Efek Pemberian Mikoriza dan Pembenah Tanah terhadap Produksi Leguminosa pada Media Tailing Liat dari Pasca Penambangan Timah," MSc Thesis, Fakultas Peternakan Institut Pertanian Bogor, 2005. [Online]. Available: http://repository.ipb.ac.id/handle/123456789/14091.

[7] T. Ibrahim, Ciri-ciri leguminosa dalam hijauan makanan ternak. Balikpapan: Balai Pengkajian Teknologi Pertanian, 2001.

[8] T. Islami and W. H. Utomo, Hubungan tanah, air dan tanaman. Semarang: IKIP Semarang Press, 2011.

[9] E. Wayah, Sudiarso, and R. Soelistyono, "Pengaruh pemberian air dan pupuk kandang sapi terhadap pertumbuhan dan hasil tanaman jagung manis (Zea mays S. L.)," Jurnal Produksi Tanaman, vol. 2, no. 2, pp. 94-102, 2014.

[10] K. R. Li, H. H. Wang, G. Han, Q J. Wang, and J. Fan, "Effects of brassinoline on the survival, growth, and drought resistance of Robinia pseudoacacia seedlings under waterstress," New Forests, vol. 35, no. 2, pp. 255-266, 2008.

[11] Cook, et. al., Tropical Forage: An Interactive Selection Tool, [CD-ROM], CSIRO, DPI\&F(Qld), CIAT and ILRI. Australia: Brisbane, 2005. 
[12] E. T. Nilsen and D. M. Orcutt, The physiology of Plants under Stress: Abiotic Factors. US: John Wiley and Sons. Inc, 2000.

[13] H. R. Kartadisastra, Penyediaan dan Pengelolaan Pakan Ternak Ruminansia. Yogyakarta: Kanisius, 1997.

[14] Immawatitari, "Analisis proksimat bahan kering," March 3, 2014. [Online]. Available: http:immawatitariwordpress.com.

[15] S. M. Sitompul and B. Guritno, Analisis Pertumbuhan Tanaman. Yogyakarta: Gadjah Mada University Press, 1995.

[16] S. Susetyo, I. Kismoro and B. Soewardi, Hijauan Makanan Ternak. Jakarta: Dirjen Peternakan, Departemen Pertanian, 2001. 